\title{
SEMANTIK ANALISIS TAGLINE DI INSTAGRAM UNTUK MEMPROMOSIKAN PARIWISATA MICE (Studi Kasus: Akun Bisnis Phenom Event)
}

\author{
Luh Mega Safitri \\ Email: mega.safitri@pib.ac.id \\ POLITEKNIK INTERNATIONAL BALI
}

\begin{abstract}
The study, entitled "Semantic Analysis of Tagline on Instagram to Promote MICE Tourism (Study Case: Phenom Event)", focuses on the meaning of the English tagline found in the event organizer Instagram's advertisements. This study aims to identify, analyze, and describe the types of meanings and implicature factors in the English tagline. Data were collected from several English taglines posted on Instagram and in analyzing the data, the writer used Leech's (1974) theory about two types of meaning and Palmer's theory about the meaning aspect (1976). The two types of meaning are conceptual (denotative) and associative meanings which are divided into six subtypes: connotative, social, affective, collocative, reflective, and thematic. Palmer (1976) distinguishes aspects of meaning into four types, namely aspects of sense (sense), aspects of feeling (feeling), aspects of tone (tone) and aspects of purpose (intention). The results showed that the types of sentence meanings in the tagline contained 5 conceptual meanings (denotative), 22 connotative meanings, and 4 affective meanings. The results also showed that the aspect of the meaning of persuasive goals was mostly used in tagline's posts on Instagram. The factors that affected implicature were intention and path factors. The tagline is used as a media to increase brand awareness and marketing strategies by using short, concise, and effective writing.
\end{abstract}

Keywords: Semantic Analysis, Tagline, Instagram, Tourism of MICE

\begin{abstract}
ABSTRAK
Penelitian yang berjudul Semantik Analisis Tagline di Instagram Untuk Mempromosikan Pariwisata MICE (Studi Kasus: Akun Bisnis Phenom Event), fokus pada makna tagline berbahasa Inggris yang terdapat pada iklan instagram event organizer. Penelitian ini bertujuan untuk mengidentifikasi, menganalisis, dan mendeskripsikan jenis-jenis makna dan faktor implikatur dalam tagline berbahasa Inggris. Data dikumpulkan dari beberapa tagline bahasa Inggris yang diposting di instagram dan dalam menganalisis data, penulis menggunakan teori dari Leech (1974)
\end{abstract}


tentang dua jenis makna dan teori dari Palmer tentang aspek makna (1976). Kedua jenis makna tersebut adalah makna konseptual (denotatif) dan makna asosiatif yang terbagi menjadi enam sub jenis: konotatif, sosial, afektif, kolokatif, reflektif, dan tematik. Palmer (1976) membedakan aspek makna menjadi empat jenis yaitu aspek pengertian (sense), aspek rasa (feeling), aspek nada (tone) dan aspek tujuan (intention). Hasil penelitian menunjukkan bahwa jenis-jenis makna kalimat dalam tagline tersebut mengandung lima makna konseptual (denotatif), 22 makna konotatif, dan empat makna afektif. Hasil penelitian juga menunjukkan bahwa aspek makna tujuan persuasif paling banyak digunakan dalam postingan tagline di instagram. Faktor-faktor yang mempengaruhi implicature yakni faktor tujuan dan jalur. Tagline digunakan sebagai media untuk meningkatkan brand awareness dan strategi marketing dengan menggunakan tulisan yang singkat, padat dan efektif.

Kata Kunci: Analisis Semantik, Tagline, Instagram, Pariwisata MICE

\section{Pendahuluan}

Pada era globalisasi ini, perkembangan perusahaan event organizer semakin menunjukkan tren positif. Persaingan antara pengusaha event organizer pun sangat ketat. Mulai dari ide gila sebuah acara, penentuan lokasi acara serta tagline yang diposting di media sosial menjadi bagian penting yang harus dipertimbangkan. Menurut Rahayuni (2017:1), Tagline merupakan kalimat, tuturan dan perkataan yang mencolok, menarik serta mudah untuk diingat yang berfungsi untuk memberitahu atau menjabarkan tujuan suatu organisasi, ideologi golongan, partai politik dan sebagainya. Tagline merupakan tulisan dari sebuah pesan iklan yang merangkum gagasan utama dalam beberapa kata yang mudah diingat. Tagline digunakan untuk menyampaikan maksud yang ingin disampaikan oleh pembuat tagline.

Pengusaha event organizer membuat tagline sekreatif mungkin untuk menarik perhatian pembaca agar mau menggunakan jasa yang ditawarkan serta memberikan kesan menarik pada acara yang diselenggarakan. Maka dari itu tagline harus memperhatikan penggunaan 
bahasa yang menarik sehingga pesan bisa tersampaikan dengan efektif dan tepat sasaran. Mempelajari tentang makna berarti mempelajari bagaimana pemakai bahasa dalam suatu kelompok sosial menafsirkan lambanglambang bahasa tersebut sehingga pesannya bisa dimengerti. Bahasa memiliki beragam makna yang dapat diinterpretasi oleh setiap orang yang membaca tulisan tersebut. Setiap tagline Bahasa Inggris yang diposting pastilah memiliki makna dan maksud yang berbeda-beda. Akan tetapi banyak pembaca yang belum memahami makna maupun maksud dari postingan tagline tersebut sehingga terjadi kesalahpahaman.

Berdasarkan latar belakang masalah tersebut, penulis tertarik untuk melakukan penelitian mengenai analisis semantik tagline berbahasa Inggris yang terdapat dalam postingan instagram Phenom Event. Penulis ingin menganalisis makna semantik dengan meninjau makna dari tagline serta mengungkap jenis-jenis makna yang terdapat dalam postingan tersebut serta mengetahui beberapa faktor yang mempengaruhi penggunaan implicature sehingga dapat memudahkan pembaca dan konsumen untuk memahami pesan yang ingin disampaikan.

\section{Konsep dan Teori}

Konsep dan teori, diantaranya adalah pengertian semantik, tipetipe makna serta aspek makna.

\subsection{Semantik}

Berdasarkan pendapat Chaer (1995:2) kata semantik dalam bahasa Indonesia (Inggris: semantics) berasal dari bahasa Yunani sema (kata benda yang berarti tanda atau lambang). Semanio memiliki pengertian menandai atau melambangkan. Menurut Aminuddin (2011: 15) semantik berasal dari bahasa Yunani yaitu to signify yang berarti memakai. Semantik merupakan istilah teknis juga memiliki pengertian "studi tentang makna", dengan anggapan bahwa menjadi bagian dari 
bahasa, maka semantik merupakan bagian dari linguistik. Menurut Tarigan (1985:5) semantik merupakan tanda-tanda atau lambanglambang yang menyatakan makna, hubungan antara makna yang satu dengan yang lainnya serta pengaruh makna tersebut terhadap manusia dan masyarakat.

Maka dari itu, semantik meliputi makna-makna kata, perkembangannya dan perubahannya. Kridalaksana (2005:132) mengemukakan bahwa semantik adalah 1) bagian struktur bahasa yang berhubungan dengan makna ungkapan dan juga dengan struktur makna suatu wicara, 2) sistem dan penyelidikan makna dan arti dalam suatu bahasa atau pada umumnya. Menurut Verhaar (2006:13) semantik adalah cabang linguistik yang membahas arti atau makna.

Berdasarkan pendapat dari para ahli maka dapat ditarik kesimpulan bahwa semantik adalah struktur bahasa yang berhubungan dengan makna ungkap dan makna wicara. Semantik merupakan ilmu tentang makna atau arti. Semantik adalah cabang ilmu linguistik tentang makna yang berarti menandai atau melambangkan.

\subsection{Tipe-Tipe Makna}

Leech (1974) membedakan tipe makna menjadi 2 bagian yaitu:

1. Makna Konseptual

Makna konseptual disebut juga sebagai makna 'denotatif' atau 'kognitif', yang berarti makna sebenarnya atau makna yang menekankan pada definisi makna itu sendiri.

2. Makna Asosiatif

Makna asosiatif mempunyai makna yang lebih tersirat dari makna konseptual dan lebih berhubungan dengan tingkat kepahaman mental seseorang. Makna asosiatif dapat dibagi menjadi 6 tipe, yaitu:

a. Makna Konotatif 
Makna konotatif merupakan nilai komunikatif dari sebuah kalimat yang diacu dan kalimat tersebut memiliki makna yang melebihi dari makna sebenarnya.

b. Makna Sosial

Leech menyatakan bahwa makna sosial merupakan makna sebuah kata yang menunjukkan lingkungan sosial penggunanya misalnya dialek yang menunjukkan asal usul dari pembicara.

c. Makna Afektif

Makna afektif dapat didefinisikan sebagai makna yang menyatakan perasaan pribadi penutur termasuk sikapnya yang berkenaan dengan perkataannya.

d. Makna Kolokatif

Berdasarkan pendapat Leech makna kolokatif memiliki asosiasiasosiasi dari suatu kata yang muncul dalam lingkungan kata-nya. Kata dan kalimat yang berkolokasi telah memiliki pasangannya sendiri.

e. Makna Reflektif

Makna reflektif merupakan makna yang muncul dalam makna konseptual ganda dimana pengertian suatu kata membentuk pengertian lain.

f. Makna Tematik

Menurut pendapat Leech makna tematik merupakan makna yang dikomunikasikan oleh penutur atau penulis dengan cara mengatur pesannya dalam arti urutan, fokus, dan penekanan.

\subsection{Aspek Makna}

Menurut Palmer (1981), aspek makna dapat dibedakan menjadi beberapa bagian: 


\section{a. Sense (Pengertian)}

Aspek makna sense (pengertian) dapat tercapai apabila antara pembicara atau penulis dan lawan bicara atau pembaca menggunakan bahasa yang sama. Makna sense (pengertian) dapat disebut juga sebagai tema, dalam hal ini melibatkan ide atau pesan yang dimaksud. Komunikasi antara pembicara dengan pendengar/pembaca harus mempunyai Bahasa yang sama supaya komunikasi dapat berjalan dengan lancar dan pesan yang ingin disampaikan pembicara dapat tersampaikan dengan baik.

b. Feeling (Perasaan).

Aspek makna feeling (perasaan) merupahan hal yang berhubungan dengan sikap pembicara atau penulis. Aspek makna perasaan menggunakan kata-kata yang sesuai dengan situasi perasaan pembicara. Contoh-contoh aspek makna feeling (perasaan) misalnya sedih, panas, dingin, gembira, gatal, jengkel. Kata-kata yang muncul dari perasaan merupakan jenis ekspresi yang berhubungan dengan pengalaman hidup, maka dari itu pernyataan situasi yang berhubungan dengan aspek makna perasaan menggunakan kata-kata berdasarkan situasi. Jadi dapat disimpulkan bahwa nilai rasa merupakan nilai yang berhubungan dengan perasaan pembicara yang akhirnya dapat mempengaruhi sikap pembicara dalam menyampaikan pesan.

c. Tone (Nada)

Aspek makna tone (nada) merupakan sikap pembicara terhadap lawan bicara yang meliputi tinggi rendahnya intonasi suara. Aspek makna tone (nada) sangat berkaitan dengan aspek makna perasaan. Contohnya, ketika kita merasa jengkel maka akan menggunakan nada meninggi, kondisi tersebut berbeda Ketika kita dalam kondisi iba atau membutuhkan bantuan seseorang maka akan menggunakan nada merata atau merendah. Aspek makna yang berhubungan dengan nada lebih tinggi dipengaruhi oleh hubungan antara pembicara dengan pendengar. Jadi dapat 
disimpulkan bahwa aspek nada adalah gabungan antara nada, tekanan, durasi dan kesenyapan.

\section{d. Intension (Tujuan)}

Aspek makna intention (tujuan) adalah tujuan atau maksud yang disadari maupun tidak. Maksud menyangkut segi subjektif si pemakai Bahasa. Tujuan maksud adalah efek yang ingin dicapai oleh pembicara atau penulis, Dalam hal ini, memahami suatu hal dalam seluruh konteks merupakan suatu usaha untuk memahami makna dalam komunikasi. Kalimat atau ujaran yang disampaikan pembicara sebenarnya bertujuan untuk menyampaikan maksud tertentu kepada pendengar. Kalimat tidak langsung mengacu pada maksud yang ingin disampaikan oleh pembicara. Oleh karena itu, maksud dari pembicara harus dipahami dengan baik oleh pendengar supaya tidak terjadi kesalahpahaman dalam menafsirkan maksud tersebut. Kalimat aspek makna aspek tujuan selalu mempunyai maksud tertentu, contohnya dengan mengatakan "Penipu kau!" kalimat tersebut bermaksud agar lawan bicara mengubah Tindakan atau perilaku yang tidak diinginkan oleh pembicara. Teori maksud dan tujuan sering digunakan dalam berbagai ragam gaya bahasa yang sering dijumpai dalam tagline. Aspek makna tujuan dibagi menjadi enam yaitu :(1) deklaratif, (2) persuasif, (3) imperatif, (4) naratif, (5) politis, (6) paedagogis (pendidikan). Keenam aspek makna tujuan tersebut melibatkan fungsi bahasa di dalam komunikasi.

(1) Makna deklaratif adalah penyampaian makna dengan kalimat yang ringkas dan jelas serta berfungsi untuk memberikan informasi tanpa meminta balasan ataupun timbal balik dari orang lain.

(2) Makna persuasif adalah penyampaian makna dengan membujuk secara halus. Kalimay yang digunakan bermaksud untuk meyakinkan, mengajak, merayu ataupun membujuk seseorang agar mau atau 
berkeinginan untuk melakukan perbuatan atau aktivitas yang disampaikan oleh pembicara.

(3) Imperatif adalah penyampaian makna dengan memberikan komando atau perintah. Kalimat yang digunakan berfungsi meminta atau melarang seseorang agar tidak melakukan sesuatu.

(4) Naratif adalah penyampaian makna dengan menceritakan rangkaian kejadian dari suatu hal/peristiwa.

(5) Politis adalah penyampaian makna dengan memberikan cara bertindak yang biasanya berhubungan dengan kekuasaan.

(6) Paedagogis adalah penyampaian makna bersifat memberikan pengetahuan serta mendidik.

Dapat disimpulkan bahwa makna kata merupakan pengaruh satuan bahasa dalam pemakaian serta hubungan bahasa dengan alam di luar bahasa. Teori aspek makna sangat berhubungan erat dengan macammacam makna.

\section{Metode}

Penelitian ini didesain sebagai sebuah penelitian deskritif kualitatif. Penelitian ini bertujuan untuk mendeskripsikan makna semantik pada postingan tagline Berbahasa Inggris di akun bisnis event organizer. Objek penelitian berupa postingan gambar visual maupun caption tagline pada akun Instagram Phenom Event. Postingan-postingan slogan tersebut selanjutnya di kumpulkan dan di screenshoot.

Penelitian ini menggunakan teknik purposive sample atau sampel bertujuan untuk mendapatkan data. Teknik purposive sample merupakan proses penyeleksian agar dalam pelaksanaan penelitian atau dalam pemilihan sampel lebih terarah dan tepat pada permasalahan yang dibahas. Penentuan data pada penelitian ini dilakukan dengan teknik analisis kutipan langsung. Pemilihan kalimat dilakukan berdasarkan kriteria yang 
telah ditentukan dan ditetapkan berlandaskan tujuan penelitian. Adapun kriteria data yang ditunjuk atau dipilih dalam penelitian ini adalah data dalam bentuk tagline Berbahasa Inggris yang mengandung makna semantik. Data yang terkumpul kemudian dianalisis dan diintepretasikan untuk kemudian dapat ditarik kesimpulan.

\section{Hasil dan Pembahasan}

\subsection{Tipe-Tipe Makna}

Berdasarkan penelitian yang dilakukan, penulis memperoleh 32 tagline Berbahasa Inggris dalam postingan Instagram Phenom Event. data menunjukkan bahwa terdapat 22 tagline memiliki makna asosiatif bersifat konotatif, 5 tagline memiliki makna asosiatif bersifat afektif dan 5 tagline yang memilik makna konseptual. Semua tagline yang dianalisis menggunakan Bahasa Inggris yang di ambil dari akun instragram Phenom Event.

Event tagline dipergunakan dalam setiap acara yang diselenggarakan oleh event organizer, jadi setiap acara akan memiliki tema tagline yang berbeda-beda berdasarkan konsep acara yang mau dibuat. Makna konseptual adalah makna yang sebenarnya berdasarkan pengertian dalam kamus. Makna asosiatif bersifat konotatif adalah makna implisit dari sebuah kalimat yang melebihi dari makna sebenarnya. Sedangkan makna asosiatif bersifat afektif adalah makna yang berhubungan dengan perasaaan atau emosi penulis untuk bisa mempengaruhi dan memberikan pesan kepada pembaca agar mau melakukan hal seperti yang disarankan. Dari hasil penelitian dapat dilihat bahwa event organizer lebih sering menggunakan kalimat yang mengandung makna konotatif atau implisit untuk menyampaikan pesan kepada klien. Hasil dari analisis data dapat dilihat pada tabel berikut ini: 
Tabel 1. Tagline berbahasa Inggris pada akun Phenom Event

\begin{tabular}{|c|c|}
\hline Tipe Makna & Jumlah \\
\hline Konseptual & 5 \\
\hline Asosiatif & 27 \\
\hline
\end{tabular}

Berdasarkan tabel 1, pembahasan tentang tipe makna adalah sebagai berikut:

1. "Build Event, Build People"
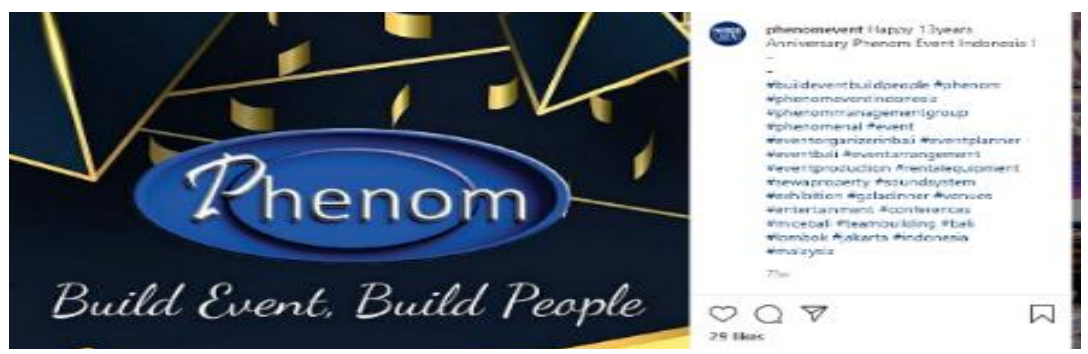

Gambar 4.1 Tagline Build Event, Build People

Sumber: Postingan Instagram Phenom Event tanggal 16 Mei 2019

Dalam kalimat tagline "Build Event, Build People" mempunyai arti membangun event, membangun orang menunjukkan makna asosiatif. Makna tersebut muncul pada pada kata build dan people yang bersifat konotatif karena melebihi dari makna yang sebenarnya. Klausa build people merujuk pada pengertian mengembangkan dan memperkuat tim agar menjadi lebih solid dan kompak.

2. "Grow Together in Mutual Satisfaction"
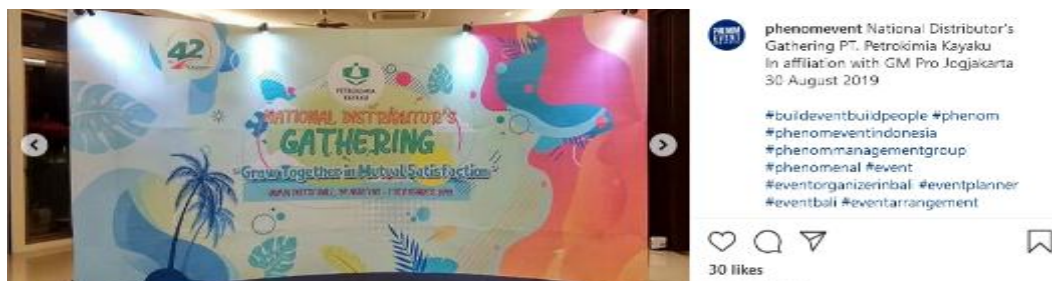

Gambar 4.2 Tagline Grow Together in Mutual Satisfaction

Sumber: Postingan Instagram Phenom Event tanggal 2 September 2019

Dalam kalimat tagline "Grow Together in Mutual Satisfaction" memiliki pengertian tumbuh bersama didalam kepuasan bersama yang menunjukkan makna asosiatif bersifat konotatif. 
Dimana pada kenyataan kita tidak bisa tumbuh dalam sebuah kepuasan. Pengiklan membuat tagline tersebut untuk menyatakan bahwa suatu organisasi bisa berkembang dengan baik jika bisa mencapai kepuasan yang tinggi dari konsumennya juga. Jadi kata "together" di sini merujuk pada Phenom Event dan konsumennya.

3. "Shaping future, Realizing Dreams"
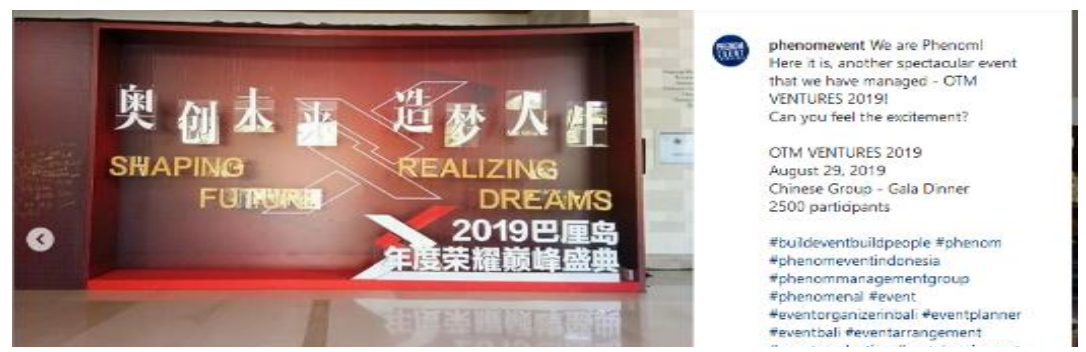

Gambar 4.3 Tagline Shaping Future, Realizing Dreams

Sumber: Postingan Instagram Phenom Event tanggal 29 August 2019

Dalam kalimat "Shaping Future, Realizing Dream" memiliki pengertian membentuk mimpi, mewujudkan masa depan. Jadi dalam kalimat ini memiliki makna asosiatif bersifat konotatif. Dalam konteks ini tagline merujuk ke makna kalimat yang melebihi dari arti yang sebenarnya yaitu jika pembaca menginginkan masa depan yang baik maka hal pertama yang harus dilakukan adalah menyadari mimpimimpi tersebut terlebih dahulu.

4. "In Unity We Run"
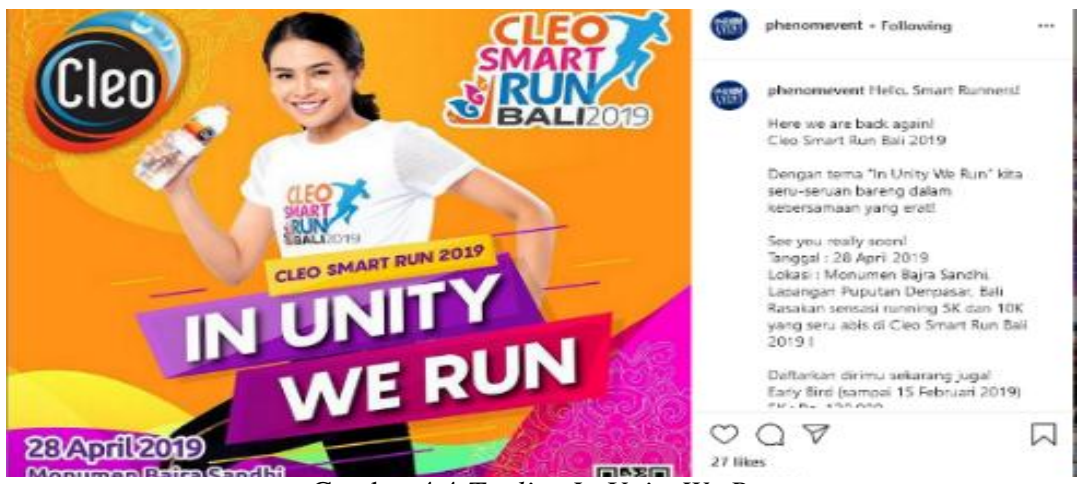

Gambar 4.4 Tagline In Unity We Run

Sumber: Postingan Instagram Phenom Event tanggal 29 Januari 2019 
Dalam kalimat “In Unity We Run” mengandung makna asosiatif bersifat konotatif. Jika diterjemahkan secara konseptual, kalimat tersebut berarti "Dalam kesatuan kita berlari”. Kata "unity" disini memiliki arti "sifat tunggal" yang berarti beberapa orang atau rombongan sedang melakukan kegiatan secara bersama-sama. Dan dalam konteks ini Phenom event menyelengggarakan event lari bersama yang diadakan di lapangan Puputan Bali. Jadi tagline ini bersifat persuasif untuk mengajak masyarakat untuk mengikuti kegiatan ini.

5. "Healthy Life, Healthy Work"

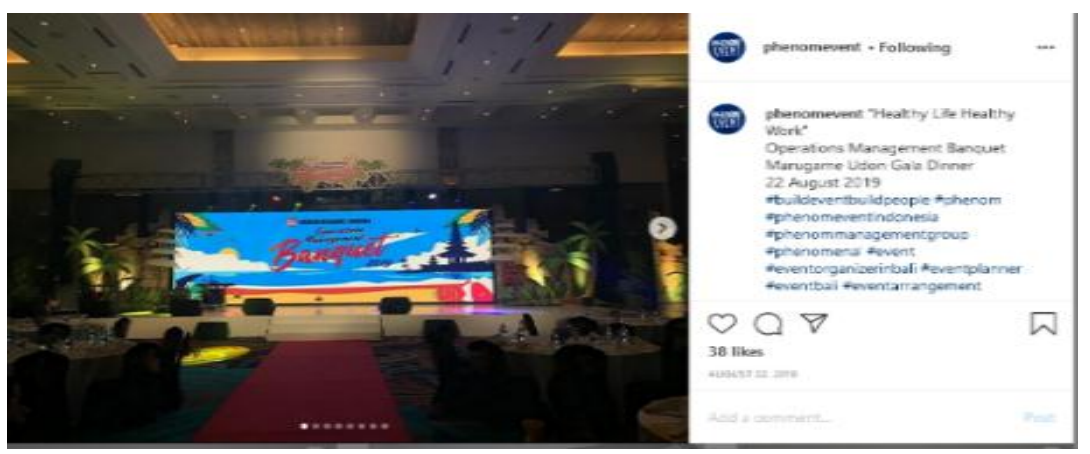

Gambar 4.5 Tagline Healthy Life, Healthy Work

Sumber: Postingan Instagram Phenom Event tanggal 22 Agustus 2019

Dalam kalimat tersebut memiliki 2 klausa yaitu "Healthy Life" dan "Healthy Work". Kalimat tersebut bisa digolongkan ke dalam makna asosiatif yang bersifat konotatif. Jika di terjemahkan dikamus, "Healthy Life, Healthy Work" memiliki pengertian "Hidup Sehat, Pekerjaan Sehat". Dalam hal ini, kata "pekerjaan" di konotasikan layaknya benda hidup dan berada dalam kondisi yang sehat. Pengiklan ingin mengimplikasikan bahwa jika kita mampu menjaga tubuh kita dengan baik dan mengikuti pola hidup yang sehat maka segala bentuk pekerjaan akan bisa terselesaikan dengan baik. 
6. "Teamwork Makes Dream Work"
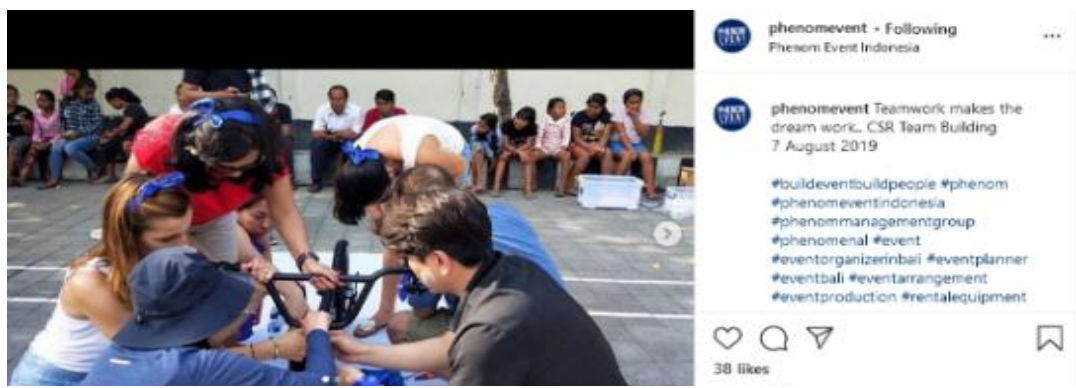

Gambar 4.6 Tagline Teamwork Makes Dream Work

Sumber: Postingan Instagram Phenom Event tanggal 22 Agustus 2019

Tagline "Teamwork Makes Dream Work" jika diterjemahkan berdasarkan kamus berarti "Kerja dalam tim Membuat Impian Bekerja "yang menunjukkan makna asosiatif bersifat konotatif. Kata "Impian" di konotasikan seolah-olah bisa bekerja selayaknya manusia. Dalam konteks ini pengiklan ingin mengimplikasikan bahwa kerja tim yang baik akan memberikan pengaruh yang positif terhadap tujuan. Jika tim solid maka seluruh tujuan dari organisasi akan tercapai dengan baik.

7. "Dream Big"
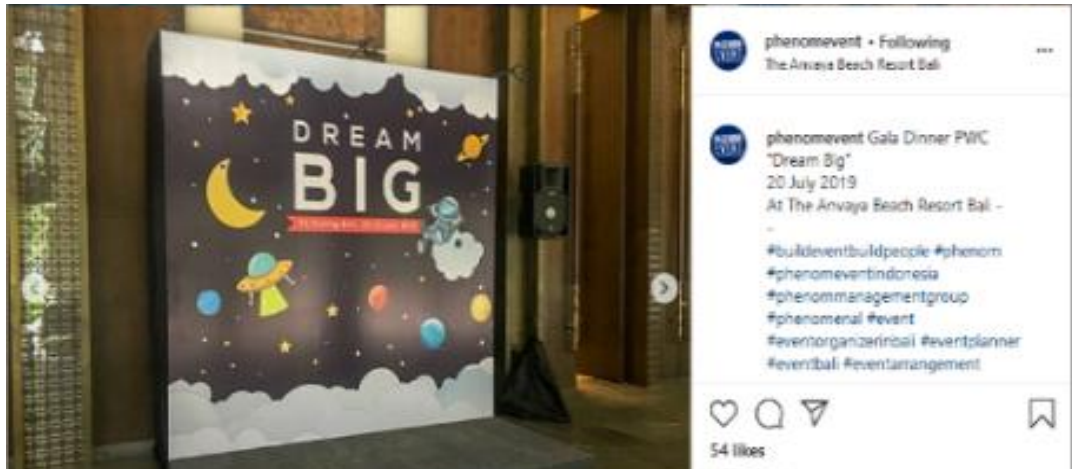

Gambar 4.7 Tagline Dream Big

Sumber: Postingan Instagram Phenom Event tanggal 22 Juli 2019

Tipe makna asosiatif yang bersifat konotatif muncul pada tagline ini. Hal ini bisa dilihat pada kata "big". Jika didefinisikan secara konseptual, "big" memiliki arti besar. Tagline ini akan membingungkan pembaca jika hanya dilihat menurut makna kamus 
saja. Kata "dream" biasanya dipasangkan dengan kata "high", tetapi dalam slogan ini pengiklan lebih memilih kata "big". Hal tersebut lebih menarik digunakan yang bertujuan persuasif.

8. "Together Towards Tomorrow"

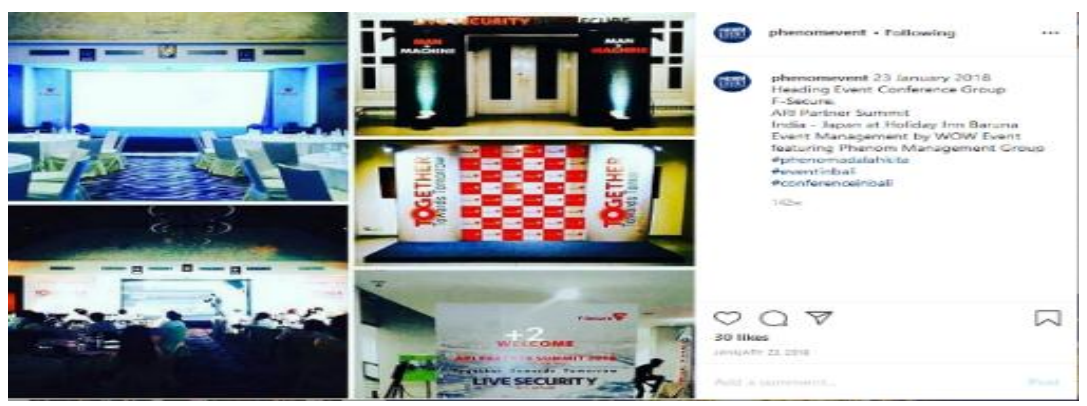

Gambar 4.8 Tagline Together Towards Tomorrow

Sumber: Postingan Instagram Phenom Event tanggal 23 Januari 2018

Dalam kalimat tagline "Together Towards Tomorrow" mengandung makna "Bersama Menuju Esok" yang menunjukkan makna kalimat asosiatif bersifat konotatif. Jadi phenom menyelenggarakan kegiatan Heading Event Conference dari group $F$ secure. Dalam konteks ini event organizer ingin mengimplikasikan bahwa acara koferensi tersebut bertujuan untuk membahas permasalahan demi mencapai tujuan bersama kedepannya.

\subsection{Tipe-Tipe Makna}

Faktor yang mempengaruhi penggunaan kalimat implicature dalam tagline Berbahasa Inggris tersebut yaitu faktor tujuan tutur dan jalur tutur. Faktor tujuan mengacu pada suatu hal yang ingin didapatkan dalam sebuah proses tindak tutur. Selain itu faktor jalur juga mempengaruhi terjadinya implicature. Faktor jalur mengacu pada jalur yang digunakan untuk menyampaikan infromasi baik secara lisan maupun tulisan. Dalam penelitian ini, event organizer menggunakan jalur tulisan dalam bentuk tagline berbahasa Inggris. 
Faktor tujuan merupakan hal yang paling dominan yang dapat mempengaruhi penggunaan kalimat implicature dalam tagline pada postingan instagram event organizer. Kalimat implicature pada tagline digunakan untuk meningkatkan brand awareness terhadap perusahaan. Tagline adalah perwujudan dari visi dan misi perusahaan. Brand dari event organizer harus mampu meningkatkan keputusan penggunaan jasa oleh konsumen, memupuk loyalitas serta meningkatkan eksistensi organisasi tersebut. Mengingat persaingan dengan penyedia pelayanan jasa acara yang sejenis sangat ketat, maka iklan yang efektif mampu memengaruhi afeksi dan kognisi serta perilaku klien. Jadi dapat disimpulkan bahwa tagline yang efektif merupakan tagline yang dapat meningkatkan brand awareness dari perusahaan. Tujuan iklan yaitu untuk mengenalkan atau meningkatkan pengetahuan client tentang brand yang diiklankan tersebut. Selain itu tagline merupakan strategi marketing yang paling ampuh untuk memengaruhi afeksi dan kognisi serta perilaku konsumen hingga sampai pada tahap keputusan penggunaan jasa event organizer yang bersangkutan. Tagline harus mampu meningkatkan keputusan pembelian konsumen.

Dalam penelitian ini, jalur yang digunakan dalam menyampaikan informasi adalah berupa jalur tulisan. Jadi timbulnya kalimat implicature pada tagline juga dipengaruhi karena penggunaan jalur tulisan. Tulisan tagline dibuat sesingkat, sepadat dan sefektif mungkin namun mengandung makna dan pesan yang luas. Tulisan singkat tersebut harus bisa mewakili seluruh pesan yang ingin disampaikan pembuat tagline kepada pembaca. Tagline yang efektif harus dibentuk atas beberapa kriteria seperti mudah diingat, kalimat yang padat serta memiliki keunikan tersendiri. Padat disini mempunyai arti bahwa suatu tagline haruslah kalimat pendek yang mampu memberi pengalaman dan kesan yang tidak gampang dilupakan oleh klien. Mudah diingat karena tagline tersebut sangat mengena dan mempunyai makna tertentu di hati klien. Sedangkan 
memiliki keunikan tersendiri berarti tagline tersebut mampu membedakan dengan pelayanan jasa sejenis di pasar.

\section{Simpulan dan Rekomendasi}

Penggunaan jenis makna tersebuat sangat berhubungan erat dengan aspek makna tujuan. Sebagian besar tagline Berbahasa Inggris memiliki makna tujuan persuasif yang dibuktikan dengan penggunaan makna asosiatif. Faktor yang mempengaruhi penggunaan implicature pada tagline yakni faktor tujuan dan faktor jalur. Faktor tujuan ialah untuk meningkatkan brand awareness, loyalitas konsumen serta strategi marketing yang efektif. Faktor jalur ialah cara yang digunakan untuk menyampaikan informasi yakni berupa tulisan yang singkat dan padat. Tagline ditulis sepadat, sekreatif dan memiliki makna tersembunyi sesuai dengan teori jenis-jenis makna dengan tujuan untuk meningkatkan penjualan pelayanan jasa event organizer, meningkatkan brand awareness, menunjukkan komitmen dan keunggulan dengan pesaing, memupuk loyalitas klien serta menunjukkan visi dan misi perusahaan. Rangkaian kata dalam tagline dibuat secara unik dan berbeda-beda sesuai dengan tema acara yang akan diselenggarakan oleh event organizer yang bersangkutan. Jadi hal tersebutlah yang mendasari penggunaan makna implicature pada tagline.

Peneliti merekomendasikan agar dilakukan penelitian lanjutan dibidang yang sama dengan menggunakan kajian data dan sumber data lain agar hasil penelitian lebih bervariasi sebagai contoh video iklan di youtube yang dapat memberikan sumbangan lebih banyak pada pembelajaran kajian ilmu linguistik. 


\section{Daftar Pustaka}

Aminuddin. 2011. Semantik Pengantar Studi tentang Makna. Bandung: Sinar baru Agensindo

Candra, Eva Nurul. 2013. "Meaning analysis of English Slogans Advertisement". Jurnal. Jakarta: Universitas Indraprasta PGRI

Chaer, Abdul. 2009. Pengantar Semantik Bahasa Indonesia. Jakarta: PT Rineka Cipta

Djajasudarma, T. Fatimah. 1999. Semantik 2, Pemahaman Ilmu Makna. Bandung: PT Refika Aditama. . 1993. Metode Linguistik: Ancangan Metode

Penelitian dan Kajian. Jakarta: Refika Aditama

Leech, Geoffrey. 1966. English in Advertising. London: Longman 1974. Semantics. London: Penguin

Kridalaksana, Harimurti. 2005. Kelas Kata Dalam Bahasa Indonesia. Jakarta: PT Gramedia Pustaka Utama

Palmer, Frank Robert. 1981. Semantics. : Cambridge University Press Diakses pada https://books.google.co.id/books/about/Semantics.html?hl=id\&i d=UWJSaxH9GiMC\&redir_esc =y

Purwoko. 2012. "Strategi Pemasaran Pengusaha Event Organizer Dalam Pariwisata MICE Di Yogyakarta". Jurnal. Yogyakarta: MKP UGM Yogyakarta

Rahayuni, Ayu Puji. 2017. "Analisis semantik slogan-slogan di lingkungan sekolah (studi kasus di Mi Tarbiyatul Aulat Jombor, Kecamatan Tuntang Kabupaten Semarang)". Jurnal. Semarang: Institut Agama Islam Negeri Salatiga

Tarigan, Henry Guntur. 1986. Pengajaran Semantik. Bandung: Angkasa

Verhaar, J.W.M. 2006. Asas-asas Linguistik. Yogyakarta: Gadjah Mada University Press

\section{Profil Penulis}

Luh Mega Safitri, S.Pd., M.Pd. adalah Dosen Program Studi D-IV Pengelolaan Konvensi \& Peristiwa di Politeknik International Bali. Lahir di Desa Gesing, 12 Juni 1989. Menyelesaikan Diploma III Bahasa Inggris di Universitas Pendidikan Ganesha pada tahun 2010. Melanjutkan Strata 1 Program Studi Pendidikan Bahasa Inggris di STKIP Agama Hindu Singaraja pada tahun 2012. Melanjutkan Pendidikan Strata 2 di Universitas Pendidikan Ganesha dengan mengambil Program Studi Pendidikan Bahasa Inggris yang diselesaikan pada tahun 2014. 
Luh Mega Safitri

56 JOURNEY Volume 3 Nomor 1, Desember 2020 